\title{
Job satisfaction among community pharmacy professionals in Mekelle city, Northern Ethiopia
}

This article was published in the following Dove Press journal:

Advances in Medical Education and Practice

21 September 2016

Number of times this article has been viewed

\section{Yared Belete Belay}

Pharmacoepidemiology and Social Pharmacy Course and Research Team, Department of Pharmacy, Mekelle University, Mekelle, Ethiopia

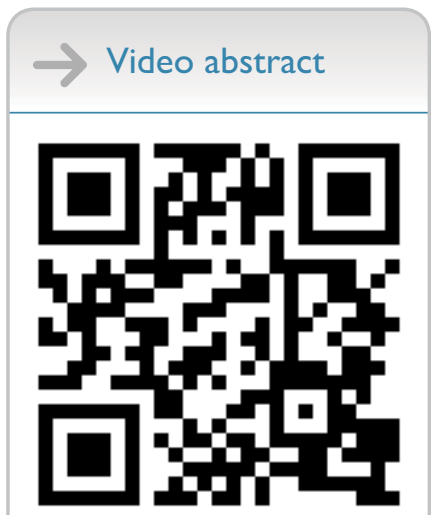

Point your SmartPhone at the code above. If you have a QR code reader the video abstract will appear. Or use: http://youtu.be/FBSDGm3V3bk
Correspondence: Yared Belete Belay Pharmacoepidemiology and Social Pharmacy Course and Research Team, Department of Pharmacy, Mekelle University, PO Box 187I, Mekelle, Ethiopia

Tel +25I 9I 2854443

Email yaredbeleteb@gmail.com
Introduction: Job satisfaction is a multidimensional, enduring, important, and much-researched concept in the field of organizational behavior and has been identified as recognition in one's field of work, level of salary, opportunities for promotion, and achievement of personal goals. Job satisfaction directly affects the labor market behavior and economic efficiency by means of the impact on productivity and turnover of staff. The aim of this study was to assess the satisfaction level of pharmacy professionals in Mekelle city.

Methods: This institution-based cross-sectional study was conducted as a survey and only included voluntary participants. Those participants who did not volunteer to participate were excluded from the study. A structured questionnaire was used as a data collection tool; it was developed from different literature in the English language, and then the original tool was translated to the local language for the purpose of understanding.

Results: In Mekelle, $\sim 100$ pharmacy professionals work in private medicine retail outlets. From those, only 60 volunteered to participate in this study. Significant difference in job satisfaction and job stress were observed between those working full-time and part-time, with $P$-values of 0.031 and 0.021 , respectively.

Conclusion: From the findings of the current study, it can be concluded that around two-thirds of pharmacy professionals in Mekelle city were satisfied with their professional practice.

Keywords: job satisfaction, pharmacy professionals and retail outlets

\section{Introduction}

Job satisfaction is a multidimensional, enduring, important, and much-researched concept in the field of organizational behavior and has been identified as recognition in one's field of work, level of salary, opportunities for promotion, and achievement of personal goals. Job satisfaction directly affects labor market behavior and economic efficiency by means of the impact on productivity and turnover of staff; ${ }^{1}$ poor job satisfaction is directly associated with performance, especially for professionals like pharmacists. ${ }^{2}$

Different factors contribute to job satisfaction such as perceived workload, information technologies, continuing pharmacy education, preceptorship, treatment by management, and other interpersonal interactions, including patient contact and coworker relationships. ${ }^{3}$ Job satisfaction is a function of career commitment in pharmacists; those committed to their careers and profession will be more satisfied with their current jobs. ${ }^{4}$ A study done in Ireland showed that $57 \%$ of community pharmacists were satisfied with their current job "most of the time" and only 5\% said they were never or rarely satisfied with their current job. Sixty percent of hospital pharmacists were satisfied with their current job "most of the time". A study conducted in Ireland reported that 
being interrupted by telephone calls, excessive/increased workloads, and not having enough staff are the most common reasons causing stress among pharmacy professionals. ${ }^{5}$

Health care systems cannot function effectively without a sufficient number of skilled, motivated, and supportive health workers, so for effective functioning of any professional practice, satisfaction is the basic requirement. ${ }^{6}$ A study from Saudi Arabia reported that pharmacists had low levels of satisfaction in three areas, which included skills utilization, professional development, and income. ${ }^{7}$

A pharmacist is a practitioner who has a bachelor's degree in pharmacy from a recognized institution and is registered with a licensing authority to practice pharmacy services. Any pharmacy professional may not perform any task out of his/ her authorized scope of practice and out of the practice stream in which he/she is registered. ${ }^{8}$ In Ethiopia, pharmacists are the most accessible health care professionals and their major role is compounding and dispensing of medicines. They play a major role in the delivery of medicines to clients and also contribute greatly toward ensuring the provision of quality medicine with appropriate information. ${ }^{9}$

A study reported from Ethiopia showed that pharmacists, in general, derive slightly higher than the average level of job satisfaction, with a mean score of $3.0 \pm 1.11$ (mean \pm standard deviation [SD]) on the overall job satisfaction item, in a scale of 1-5. In Ethiopia, younger pharmacists (age $\leq 30$ years) reported a lower level satisfaction than the middle age group (31-40 years) pharmacists. On the other hand, older pharmacists (age $>40$ years) reported a higher level of satisfaction for all items than the other age groups. ${ }^{10}$ A similar study in Southwest Ethiopia depicted that $59 \%$ of pharmacists were satisfied with their working position and $63 \%$ of them were satisfied with the working environment. The study also reported that $60.8 \%$ of the respondents were satisfied with their job. ${ }^{11}$

Assessing satisfaction level of pharmacists in Mekelle could make a profound contribution toward improving pharmaceutical care service and increasing customer level of satisfaction. If we know the area with low satisfaction level of pharmacists, we can put in place measures to improve it. The aim of this study was to assess the satisfaction level of pharmacy professionals in Mekelle city.

\section{Methodology}

\section{Study area and period}

The study was conducted in Mekelle city. Mekelle city is located $784 \mathrm{~km}$ north of Addis, which is the capital of Ethiopia. A total of 79 retail outlets were found in Mekelle; from these, 32 were pharmacies and 47 were drug stores.

\section{Study design}

In this study, institution-based cross-sectional study design was employed.

\section{Population}

\section{Source population}

The study included all pharmacy professionals of Mekelle city.

\section{Study population}

All pharmacy professionals who were eligible and volunteered to respond to questionnaires.

\section{Sample size determination and sampling procedure}

This study was conducted as a survey, and only included voluntary participants. In Mekelle, 100 pharmacy professionals work in private medicine retail outlets. From those, only 60 volunteered to participate in this study.

\section{Study variables}

Independent variables

Sociodemographic variables, including age and sex of respondents, educational level, working area, year of experience, and type of employment, were considered as independent variables.

\section{Dependent variables}

Job satisfaction was the outcome variable of this study.

\section{Inclusion and exclusion criteria}

All study participants who volunteered to participate were included and those who did not were excluded from the study.

\section{Data collection and management}

Data were collected by using structured questionnaires covering questions aimed at assessing the sociodemographic profiles and satisfaction related to working conditions and environment.

\section{Data quality assurance}

Pretest of the data collection tool was conducted on five pharmacy professionals. Based on the result of the pretest, necessary corrections were done.

\section{Data entry, analysis, and interpretation}

After the data were collected, they were entered and analyzed by SPSS (SPSS Inc, Chicago, IL, USA version 20). A descriptive analysis was done through calculating frequency, mean, and SDs. Statistical tests including one-way analysis of variance were done to check for association between 
sociodemographic variables and job satisfaction level. In performing the statistical analyses, $P$-value of 0.05 and confidence interval of $95 \%$ was employed.

\section{Ethical considerations}

Ethical clearance was obtained from the Ethical Review Committee of the College of Health Science, Mekelle University, for conducting the study. Pharmacy professionals to be interviewed were asked for their consent for participation.

\section{Results}

Out of the 60 participants involved in the study, 55 responded to the questionnaires appropriately and completely, which makes the response rate $91.6 \%$. Majority of the respondents were male $(\mathrm{N}=38,69.1 \%)$ and working in private pharmacies $(\mathrm{N}=44,80 \%)$ (Table 1).

More than two-thirds (69.1\%) of the respondents strongly agreed with the fact that job stress was low in drug retail outlets, and $54.5 \%$ of the pharmacy professionals claimed that the profession has a good future (strongly agree [ $\mathrm{N}=30,54.5 \%])$. Of all the study participants, $50.9 \%$ responded "strongly agree" for the question related to overall satisfaction. The result of this study showed that $44.4 \%$ participants were not satisfied with the working environment (disagree $=25.5 \%$, strongly disagree $10.9 \%$ ) (Table 2).

Normality of the distribution for age of the participants was checked through histograms, with mean age of 32.62 years and SD of 8.829 (Figure 1).

Statistical test (one-way analysis of variance) of the difference among categories of respondents was related to job satisfaction.
Significant difference in job satisfaction and job stress was observed between pharmacists working full-time and parttime, with $P$-value of 0.031 and 0.021 , respectively (Table 3 ).

\section{Discussion}

Majority of the study participants (69.1\%) were male and within the age of 20-30 years, which consists of $45.5 \%$. The mean age of the participants was 32.62 years with SD of 8.829 ; this result was comparable with the result obtained from the study that assessed workforce of pharmacists in Ethiopia, which reported that the mean age of the pharmacists was 30.2

Table I Frequency of sociodemographic and other baseline information of participants, a cross-sectional study on assessment of job satisfaction among pharmacy professionals at Mekelle city, January 2016

\begin{tabular}{lllll}
\hline $\begin{array}{l}\text { Serial } \\
\text { no }\end{array}$ & Variable & Categories & $\begin{array}{l}\text { Frequency } \\
(\mathbf{N})\end{array}$ & $\begin{array}{l}\text { Frequency } \\
\text { (\%) }\end{array}$ \\
\hline I & Age & $20-30$ & 25 & 45.5 \\
& & $31-40$ & 20 & 36.4 \\
& & $41-50$ & 7 & 12.7 \\
& & $>50$ & 3 & 5.4 \\
2 & Sex & Male & 38 & 69.1 \\
& & Female & 17 & 30.9 \\
3 & Level of & Diploma & 25 & 45.5 \\
& education & Degree & 28 & 50.9 \\
& & Master & 2 & 3.6 \\
4 & Years of & $<5$ & 18 & 32.8 \\
& experience & 5-10 & 25 & 45.5 \\
& & $>10$ & 12 & 21.7 \\
5 & Type of retail & Private pharmacy & 44 & 80 \\
& outlets & Private drug store & 10 & 18.2 \\
& & Public pharmacy & 1 & 1.8 \\
6 & Type of & Full-time & 47 & 85.5 \\
& employment & Part-time & 8 & 14.5 \\
\hline
\end{tabular}

Table 2 Response of the participants on the variables related with job satisfaction, a cross-sectional study on assessment of job satisfaction among pharmacy professionals at Mekelle city, January 2016

\begin{tabular}{|c|c|c|c|c|c|c|}
\hline $\begin{array}{l}\text { Serial } \\
\text { no }\end{array}$ & Questions & $\begin{array}{l}\text { Strongly agree } \\
\mathbf{N}(\%) \\
\end{array}$ & $\begin{array}{l}\text { Agree } \\
\text { N (\%) }\end{array}$ & $\begin{array}{l}\text { Neutral } \\
\text { N (\%) }\end{array}$ & $\begin{array}{l}\text { Disagree } \\
\mathbf{N}(\%)\end{array}$ & $\begin{array}{l}\text { Strongly disagree } \\
\mathbf{N}(\%)\end{array}$ \\
\hline I & Low job stress & $38(69.1)$ & $10(18.2)$ & $\mathrm{I}(\mathrm{I} .8)$ & $6(10.9)$ & - \\
\hline 2 & The job has good future & $30(54.5)$ & $12(21.8)$ & $6(10.9)$ & $5(9.1)$ & $2(3.6)$ \\
\hline 3 & Good recognition from the society & $27(49.1)$ & $9(16.4)$ & $6(10.9)$ & II (20) & $2(3.6)$ \\
\hline 4 & Attractive salary & $23(4 I .8)$ & $14(25.5)$ & $\mathrm{I}(\mathrm{I} .8)$ & II (20) & $6(10.9)$ \\
\hline 5 & Feeling of accomplishment from the job & $19(34.5)$ & $14(25.5)$ & $8(14.5)$ & $9(16.4)$ & $5(9.1)$ \\
\hline 6 & Freedom to choose own working method & $23(41.8)$ & II (20) & $4(7.3)$ & II (20) & $6(10.9)$ \\
\hline 7 & Good working environment & $22(40)$ & $12(2 \mid .8)$ & $4(7.3)$ & II (20) & $6(10.9)$ \\
\hline 8 & Good working position & $22(40)$ & II (20) & $2(3.6)$ & $14(25.5)$ & $6(10.9)$ \\
\hline 9 & Opportunity to choose personal abilities & $20(36.4)$ & $12(2 \mid .8)$ & $5(9.1)$ & $12(21.8)$ & $6(10.9)$ \\
\hline 10 & Good staff interaction & $23(41.8)$ & $12(21.8)$ & $\mathrm{I}(\mathrm{l} .8)$ & $15(27.3)$ & $4(7.3)$ \\
\hline II & Chance of professional development & $23(41.8)$ & $10(18.2)$ & $7(12.7)$ & II (20) & $4(7.3)$ \\
\hline 12 & Adequate training & $24(43.6)$ & $12(21.8)$ & $7(12.7)$ & $8(14.5)$ & $4(7.3)$ \\
\hline 13 & Benefit for the society & $22(40)$ & $13(23.6)$ & $3(5.5)$ & $13(23.6)$ & $4(7.3)$ \\
\hline 14 & I am satisfied with my job & $28(50.9)$ & $9(16.4)$ & $2(3.6)$ & $12(2 \mid .8)$ & $4(7.3)$ \\
\hline
\end{tabular}




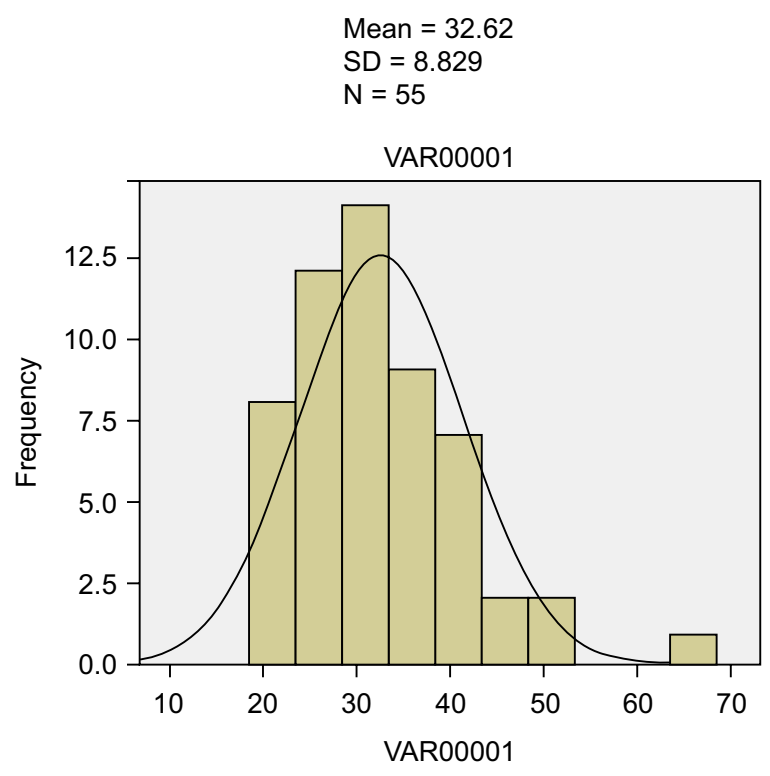

Figure I Age distribution of pharmacy professionals, a cross-sectional study on assessment of job satisfaction among pharmacy professionals in Mekelle city, January 2016. (VAR0000I = Age).

Abbreviation: SD, standard deviation.

Table 3 Association of sociodemographic characteristics with job satisfaction and stress among pharmacy professionals at Mekelle city, January 2016

\begin{tabular}{|c|c|c|c|c|}
\hline $\begin{array}{l}\text { Serial } \\
\text { no }\end{array}$ & Variable & & Groups & $\begin{array}{l}\text { Association } \\
\text { between } \\
\text { groups } \\
\text { P-value }\end{array}$ \\
\hline \multirow[t]{2}{*}{ I } & $\begin{array}{l}\text { I am satisfied } \\
\text { with my job }\end{array}$ & Age & $\begin{array}{l}\text { Male } \\
\text { Female }\end{array}$ & 0.986 \\
\hline & & $\begin{array}{l}\text { Type of } \\
\text { employment }\end{array}$ & $\begin{array}{l}\text { Full-time } \\
\text { Part-time }\end{array}$ & 0.021 \\
\hline \multirow[t]{2}{*}{2} & Low job stress & $\begin{array}{l}\text { Education } \\
\text { level }\end{array}$ & $\begin{array}{l}\text { Diploma } \\
\text { Degree } \\
\text { Master }\end{array}$ & 0.373 \\
\hline & & $\begin{array}{l}\text { Type of } \\
\text { employment }\end{array}$ & $\begin{array}{l}\text { Full-time } \\
\text { Part-time }\end{array}$ & 0.031 \\
\hline
\end{tabular}

years $\left(\mathrm{SD}=8.3\right.$, range: $21-63$ years).$^{10}$ The previous study was a nationwide study and the current study was also the reflection of the prior one. As a result of the study being conducted in the same country, the consistency of the result was not surprising.

From the participants, $67.3 \%$ were satisfied with their professional job (strongly agree $=50.9 \%$, agree $=16.4 \%$ ), which is higher than the result reported from northern Ireland that revealed that $57 \%$ of community pharmacists were satisfied with their current job 'most of the time'. ${ }^{5}$ The difference may result from difference in sample size; the previous study comprises 766 respondents, which is far higher than the current study. ${ }^{5}$ Despite the earlier result, the finding of the current study is promising when we compared it with the results from the developed country of Ireland. The current study showed no correlation between the different age and job satisfaction levels ( $P$-value $=0.986)$, which is consistent with the results of the study conducted in Saudi Arabia that showed no significant association between pharmacists' job satisfaction and age, marital status, duration at present work, monthly salary, and experience. ${ }^{7}$ But this result is not consistent with the finding of the previous study in Ethiopia, which depicted more experienced pharmacists ( $>10$ years of professional work experience) who scored a consistently higher mean on all work satisfaction items than less experienced pharmacists (both $<5$ and 5-10 years of professional work experience). ${ }^{10}$

\section{Limitation of study}

The study consisted of a small sample size, which makes generalization to all the professionals difficult.

\section{Conclusion}

From the current study, it can be concluded that there is promising satisfaction (two-thirds of the participants) status of pharmacy professionals in Mekelle city. Generally, job satisfaction and stress are closely associated with nature of employment and educational status.

\section{Disclosure}

The author reports no conflicts of interest in this work.

\section{References}

1. Vorster M. A Comparative Study on Pharmacist Job Satisfaction in the Private and Public Hospitals of the North-West Province/by Marine Vorster [dissertation]. South Africa: North-West University; 2010.

2. Saari LM, Judge TA. Employee attitudes and job satisfaction. Hum Resour Manage. 2004;43(4):395-407.

3. Hincapie AL, Yandow S, Hines S, Martineau M, Warholak T. Job satisfaction among chain community pharmacists: results from a pilot study. Pharm Pract (Granada). 2012;10(4):227-233.

4. Desselle SP, Holmes ER. Structural model of certified pharmacy technicians' job satisfaction. J Am Pharm Assoc. 2007;47(1):58-72.

5. McCann L, Hughes CM, Adair CG, Cardwell C. Assessing job satisfaction and stress among pharmacists in Northern Ireland. Pharm World Sci. 2009;31(2):188-194.

6. Mowday R. Strategies for adapting to high rate of employee turnover. Hum Resour Manage. 1984;23(4): 865-380.

7. Bawazir SA. Job satisfaction in Saudi community pharmacists.-letter. J Pharm Pract Res. 2005;35(4):334.

8. Ethiopian food, medicine and health care administration and control authority. Scope of practice for health professionals in Ethiopia. Addis Ababa: EFMHACA; 2014. Available from: http://www.fmhaca. gov.et/documents/SCOPE\%20OF\%20PRACTICE\%20FOR\%20 HEALTH\%20PROFESSIONALS\%20IN\%20ETHIOPIA.pdf. Accessed March 25, 2016.

9. Abay SM, Amelo W. Assessment of Self-medication practices among medical, pharmacy, health science students in Gondar University, Ethiopia. J Young Pharm. 2010;2(3):306-310.

10. Gebretekle GB, Fenta TG. Assessment of pharmacist's workforce in Ethiopia. Ethiop J Health Dev. 2013;27(2):124-133.

11. Ahmed SM, Tolera M, Angamo MT. Assessment of job satisfaction among pharmacy professionals in south-west Ethiopia. Int $J$ Pharm Sci Res. 2013;4(6):2351. 
Advances in Medical Education and Practice

Dovepress

\section{Publish your work in this journal}

Advances in Medical Education and Practice is an international, peerreviewed, open access journal that aims to present and publish research on Medical Education covering medical, dental, nursing and allied health care professional education. The journal covers undergraduate education, postgraduate training and continuing medical education including emerging trends and innovative models linking education, research, and health care services. The manuscript management system is completely online and includes a very quick and fair peer-review system. Visit http://www.dovepress.com/testimonials.php to read real quotes from published authors.

Submit your manuscript here: http://www.dovepress.com/advances-in-medical-education-and-practice-journal 